\title{
CRUSTAL ANATEXIS AND GRANITE GENESIS IN THE SOCORRO-GUAXUPÉ THRUST NAPPE, SOUTHEASTERN BRAZIL: SOME CONSTRAINTS FROM ELEMENTAL GEOCHEMISTRY
}

\author{
VALDECIR DE ASSIS JANASI
}

\begin{abstract}
RESUMO ANATEXIA CRUSTAL E GÊNESE DE GRANITOS, NA NAPPE DE EMPURRÃO SOCORROGUAXUPÉ, SE DO BRASIL: SUPORTE A PARTIR DA GEOQUÍMICA ELEMENTAL Três suítes de granitos foram produzidas há ca. 620-630 Ma por fusão parcial de uma secão crustal exposta como um terrene alóctone de alto grau (a Nappe de Empurrão Socorro-Guaxupé) a sul do Cráton do São Francisco, SE do Brasil. Os notáveis contrastes petrográficos e geoquímicos entre as suítes refletem sua geração a partir de diferentes protolitos sob condiçcões variáveis de $\mathrm{P}, \mathrm{T}$ e $\mathrm{a}\left(\mathrm{H}_{2} \mathrm{O}\right)$. A suíte São José do Rio Pardo (SJRP) é formada por corpos tabulares dobrados com uma associação consanguínea de rochas mangeríticas a graníticas predominante que resultou de cristalizacão fracionada in situ de magmas quartzo mangeríticos de baixo mg\#, $\mathrm{Ca}$ e $\mathrm{Sr}$. Os conteudos muito baixos de elementos tracos radiogênicos ( $\mathrm{Rb}, \mathrm{Cs}$, Th, $\mathrm{U}$ ) e $\mathrm{H}_{2} \mathrm{O}$ inferidos para os magmas parentais indicam uma fonte granulítica empobrecida que, como deduzido pela termometria de saturação em zircão, foi fundida a temperaturas anomalamente elevadas (até $1000^{\circ} \mathrm{C}$ ). Altas razões $\mathrm{K} / \mathrm{Rb}$ e $\mathrm{Ba} / \mathrm{Sr}$ e anomalias positivas de $\mathrm{Eu}$, especialmente evidentes em um conjunto de rochas charnoquíticas não-cumuláticas, parecem refletir fusão em desequilíbrio envolvendo feldspato potássico como fase consumida, provavelmente como resultado da natureza anidra dos magmas e da rápida extração do fundido. Os granitos tipo Pinhal ocorrem como inúmeros corpos pequenos de biotita granito róseo equigranular, em parte nebulítico, intimamente associado a gnaisses migmatíticos. Esses granitos são interpretados como produtos de fusão associada a quebra de biotita a ca. $850^{\circ} \mathrm{C}$ a partir de protolitos de composição tonalítica-granodiorítica, como indicam seus padrões de ETR fracionados (sugestivos da presença de granada no resíduo), além das anomalias negativas de Eu e razões $\mathrm{Rb} / \mathrm{Sr}$ mais elevadas em relação as demais suítes (ambos sugestivos de um resíduo rico em plagioclásio e pobre em biotita, possivelmente granulítico). Os granada-biotita granitos tipo Nazaré Paulista, também intimamente associados a gnaisses migmátiticos, correspondem a produtos de fusão a temperaturas mais baixas $\left(700-800^{\circ} \mathrm{C}\right.$, como inferido da termometria de satura9ao em zircao e monazita) de protolitos com um componente metassedimentar importante. Conteúdos comparativamente elevados de $\mathrm{Ca}$ e $\mathrm{Sr}$ e anomalias de $\mathrm{Eu}$ levemente positivas a nulas, além de baixos $\mathrm{Rb}$ e $\mathrm{Ba}$, indicam um residue com biotita abundante e pobre em plagioclásio ou com plagioclásio rico em $\mathrm{Ca}$. A anatexia generalizada da seção crustal neoproterozóica estudada deve refletir a influência de uma importante anomalia térmica de magnitude incomum em orógenos colisionais, que foi responsável pela geração, em um curto intervalo de tempo, de tipos de granitos normalmente encontrados em diferentes ambientes tectônicos (e.g., a suíte mangerito-charnockito-granito SJRP e os leucogranitos peraluminosos associados a suíte Nazaré Paulista).
\end{abstract}

Palavras-chaves: charnockito, granito, anatexia crustal, litogeoquímica

\begin{abstract}
Three suites of granites were produced at $c a$. 620-630 Ma by partial melting of a crustal section exposed as a high-grade allocthonous terrane (the Socorro-Guaxupé Thrust Nappe, SGTN) south of the São Francisco Craton, SE Brazil. The striking chemical and petrographical contrasts observed reflect their genesis from different protoliths under varying $\mathrm{P}, \mathrm{T}, \mathrm{a}\left(\mathrm{H}_{2} \mathrm{O}\right)$. The São José do Rio Pardo (SJRP) suite is made up of folded tabular bodies with a predominant consanguineous association of foliated mangeritic to granitic rocks which resulted mostly from in situ crystal fractionation of low $\mathbf{m g \#}$. Ca and $\mathrm{Sr}$ quartz mangeritic magmas. The very low contents of radiogenic $(\mathrm{Rb}, \mathrm{Cs}, \mathrm{Th}, \mathrm{U})$ trace-elements and $\mathrm{H}_{2} \mathrm{O}$ inferred for their parent melts imply a depleted granulite source which, as deduced from $\mathrm{Zr}$ saturation thermometry, was melted under abnormally high T (up to $1,000^{\circ} \mathrm{C}$ ). High $\mathrm{K} / \mathrm{Rb}$ and $\mathrm{Ba} / \mathrm{Sr}$ ratios and positive Eu anomalies seem to result from disequilibrium melting involving $\mathrm{K}$-feldspar as a reactant phase, probably as a reflection of the rather dry nature of the magmas and of fast rates of melt extraction. The Pinhal-type granites occur as countless small bodies of equigranular, in part nebulitic, pink biotite granite closely associated to migmatitic gneisses. These granites are interpreted as products of biotite dehydration-melting at $c a .850^{\circ} \mathrm{C}$ from tonalitic-granodiorite protoliths, as indicated by their fractionated REE patterns (suggestive of residual garnet), moderately negative $\mathrm{Eu}$ anomalies and higher $\mathrm{Rb} / \mathrm{Sr}$ as compared to the other suites (both suggestive of a plagioclaserich, biotite-poor residuum, possibly a granulite). The garnet-biotite Nazaré Paulista-type granites, also closely associated to migmatitic gneisses, correspond to products of lower-temperature $\left(700-800^{\circ} \mathrm{C}\right.$, as inferred from zircon and monazite saturation thermometry) melting of protoliths with an important metasedimentary component. Comparatively high $\mathrm{Ca}$ and $\mathrm{Sr}$ and slightly positive to negligible Eu anomalies, besides low $\mathrm{Rb}$ and $\mathrm{Ba}$ contents point to a residuum with abundant biotite and either plagioclase-poor or bearing a Ca-rich plagioclase. The widespread anatexis in this section of Neoproterozoic crust appears to reflect the influence of a huge thermal anomaly of a magnitude unusual in collisional orogens, that was responsible for the generation, in a short time interval, of granite types normally found in different tectonic environments (e.g., the SJRP mangerite-charnockite-granite suite and the peraluminous leucogranites associated to the Nazaré Paulista suite).
\end{abstract}

Keywords: charnockite, granite, crustal anatexis, lithogeochemistry

\begin{abstract}
INTRODUCTION
The chemical composition of crustal granites is controlled by a number of factors; many of these can at present be modelled quite satisfactorily owing to the impressive amount of experimental and theoretical data which has been assembled in the last years. Examples include: (1) the quantitative determination of the influence of $\mathrm{P}$ and volatile $\left(\mathrm{H}_{2} \mathrm{O}, \mathrm{HF}, \mathrm{B}\right)$ activities on the eutectic or minimum-melt composition in the haplogranitic system (Johannes \& Holtz 1990, Pichavant \& Manning 1984); (2) estimates of the composition and amount of melt produced by dehydration-melting of a series of protholiths (mostly model pelites,
\end{abstract}

tonalites, amphibolites and mixtures of them) under varying $\mathrm{T}$ and P (Clemens \& Vielzeuf 1987, Patino Douce \& Johnston 1991, Gardien et al. 1995, Rushmer 1991); (3) quantitative models for the solubility and dissolution kinetics of traceelements which are essential structural components (ESC) in accessory minerals such as zircon, monazite and apatite (Watson \& Harrison 1984, Montel 1993); (4) systematic experimental estimates of partition coefficients (D) of key trace elements between main minerals (feldspars, micas) and melt, which now in many cases can be expressed in the form 
$\mathrm{D}=\mathrm{f}(\mathrm{P}, \mathrm{T}, \mathrm{X})$ (Blundy \& Wood 1991, Icenhowen \& England 1995, 1996); and several others.

Here is presented a preliminary geochemical comparison between three types of syn-orogenic granites produced by crustal anatexis during the main metamorphic event that affected the Socorro-Guaxupe Thrust Nappe (SGTN; Campos Neto et ol. 1984), an allochtonous terrane thrust over a lower grade metavolcanosedimentary belt at the southern border of the São Francisco craton during the Brasiliano cycle (Neoproterozoic).

Two of these granite types are traditionally viewed in the local literature as typical examples of anatectic magmatism: the Pinhal and Nazaré Paulista-type granites (Wernick \& Penalva 1980, Janasi \& Ulbrich 1991). The consensus about their origin by crustal melting comes mostly from their often nebulitic character and their occurrence as countless small bodies closely associated with migmatites that exhibit leucosomes texturally identical to them. The exact age of the main regional metamorphic event responsible for their generation is however still undefined, as no reliable age determinations are available. On the basis of stratigraphic arguments, it should be confined to the 650-610 Ma period, between the older syn-orogenic calc-alkaline (continental arc-type?) magmatism and the emplacement of the younger epizonal granitic massifs that constitute the Itu province (e.g., Janasi \& Ulbrich 1991).

The third type of syn-orogenic crustal granite is represented by the gneissic mangerite-granite São José do Rio Pardo (SJRP) suite, first recognized by Campos Neto et al. (1988) and interpreted as the result of melting of a depleted granulite source (Janasi 1992, 1996). On account of its "intraplate" geochemical signature, this suite was initially interpreted as a product of some pre-orogenic extensional event; in fact, $\mathrm{Rb}$-Sr isotope data obtained in several massifs yielded disparate isochronic ages, ranging from ca. $650 \mathrm{Ma}$ (Oliveira et al. 1986) to values as old as $1300 \mathrm{Ma}$ (Campos Neto et al 1988). Recent zircon U-Pb dating of a mangerite from the Divinolandia region by two different methods (conventional thermal ionization and zircon evaporation, both quoted in Basei et al. 1995) yielded nearly identical results at 625-630 $\mathrm{Ma}$. These values fall exactly within the period inferred from stratigraphy to the main regional metamorphism, as quoted above. In spite of the gneissic character of the rocks analyzed, the zircon ages are probably magmatic, since the grains chosen for dating are typically euhedral and also U-poor, what would inhibit post-magmatic reequilibration.

The SJRP suite appears therefore to have been produced nearly contemporaneously to the other two types of anatectic granites present in the SGTN. As will be shown by geochemical data, the contrasts between the three granite types are mostly a reflection of their different crustal protoliths, as well as of differences in the physico-chemical conditions during anatexis.

\section{REGIONAL GEOLOGY The SGTN is an alloc-} thonous high-grade terrane thrust over the lower-grade metasupracrustals of the Alto Rio Grande Fold Belt (ARFB) southwest of the São Francisco craton. Post-thrusting deformation divided the terrane into two segments separated by a narrow strip where the para-authochtonous ARFB and its basement are exposed. A lower granulite belt is present in both segments, but is best preserved in the northern segment, where extreme $\mathrm{P}(\geq 11 \mathrm{kbar})$ and $\mathrm{T}\left(\mathrm{ca} .950^{\circ} \mathrm{C}\right)$ were locally identified by geothermobarometry (Vasconcellos et al 1991). Southwards the granulites grade into gneissic migmatites, mostly orthoderived, that represent shallower levels of the crustal section, in which lower pressures (6-8 kbar) and temperatures $\left(700-850^{\circ} \mathrm{C}\right)$ were estimated by several authors using different thermobarometers (e.g., Oliveira \& Ruberti
1979, Vasconcellos et al. 1991, lyer et al. 1995). Metasupracrustals (metapelites, amphibolites, quartzites) occur more frequently southwards, but only predominate over quartzofeldspatic gneisses in the southern half of the southern segment of the SGTN, which appears to represent shallower levels of the crustal slice brought up by the nappe structure. The absolute age of the protoliths of the metamorphic rocks as well as the relative ages of metasupracrustals and quartzofeldspatic gneisses are unknown. The few presently available absolute ages are restricted to intrusive granitoids and reflect to a large extent the strong Brasiliano (650-550 Ma) overprint.

The older reliably Neoproterozoic plutonic rocks present in the area are gneissified charnockites with high-K calcalkaline affinities dated at $660 \mathrm{Ma}$ by both $\mathrm{Rb}-\mathrm{Sr}$ and U-Pb methods (Figueiredo \& Campos Neto 1994, Basei et al. 1995). The huge Pinhal-Ipuiuna (Haddad 1995) and Socorro (Wernick et al. 1984) batholiths are made up of chemically expanded suites with typical high-K calc-alkaline signatures; the latter was recently dated at $629 \pm 10 \mathrm{Ma}$ by U-Pb zircon geochronology (Topfner 1996).

The São José do Rio Pardo (SJRP) suite (Campos Neto etal. 1988) comprises folded tabular bodies formed by a strongly foliated mangerite-granite association whose age relative to the calc-alkaline suite is difficult to determine by field criteria. As mentioned previously, recent $\mathrm{U}-\mathrm{Pb}$ zircon age determinations suggest their generation at ca. 625-630 Ma, which seems compatible with a syn-metamorphic anatectic origin.

Other syn-metamorphic crustal granites intrusive in both previous suites and often much less foliated are, together with the SJRP suite, the main subject of this work. The lateorogenic Itu granitic province is formed by several shallowlevel massifs that intruded the SGTN after the major vertical displacement associated to the nappe structure, at 610-580 Ma (Vlach et al. 1990).

\section{GEOLOGY AND PETROGRAPHY OF THE SYN- OROGENIC CRUSTAL GRANITES The São Jose do Rio Pardo mangerite-granite suite}

The SJRP suite occurs mostly in an irregular belt 4-6 km wide extending for some $100 \mathrm{~km}$ in the central portion of the Guaxupé Domain between the localities of Mococa (in São Paulo) and Caldas (in Minas Gerais) (Fig. 1). Although nearly continuous, the belt is constituted by several individual massifs, each one in turn formed by two or more separate intrusions (e.g., Janasi 1995). Other occurrences related to the suite are recognized north of this main belt as smaller bodies intrusive into regional granulites; in some outcrops, mangerites seem to constitute the leucosomes of the granulites.

Some of the massifs forming the main belt that were mapped in greater detail (on the 1:50,000 scale) exhibit a wide diversity of rock types (e.g., Campos Neto \& Figueiredo 1985, Janasi 1996). All rocks are strongly deformed, with grain-size reduction and nearly complete obliteration of the previous magmatic textures.

Dark-green, medium- to coarse-grained mangerites and quartz mangerites with $c a$. 10\% mafics are the predominant rock type. They are easily distinguished from the regional granulites by their coarser grain size and homogeneous textures, banding being tipically absent. Dark, finer-grained dioritic enclaves, usually rounded and centimetric to decimetric, occur quite sporadically and appear to be totally absent in some occurrences. Locally the mangerites seem to pass gradually into texturally similar pinkish hornblende granites.

More fractionated hololeucococratic pink granites (with less than $5 \%$ mafics, usually hornblende \pm biotite; in part, "alaskites") are locally abundant, and may exhibit sharp or apparently transitional contacts with the hornblende granites. 




Figure 1 - Geological sketch map of the central portion of the northern segment of the SGTN, showing the main belt of mangerite-granite massifs from the SJRP suite and their respective names.

Figura 1 - Mapa geológico simplificado da porção central do segmento setentrional da Nappe de Empurrão Socorro-Guaxupé, mostrando a faixa principal de maciços mangeríticos-graníticos da suite SJRP, e seus respectivos nomes.

Fine-grained greenish quartz mangerites to charnockites occur sporadically as decimetric bands within the coarser mangerite except in the Mococa massif (Janasi \& Invernizzi 1996) where they form a larger mappable body.

Other comparatively rare rock types include at least two different types of syenite, both occurring in the Mococa massif (Campos Neto \& Figueiredo 1985, Janasi \& Invernizzi 1995).

The mineralogy of the less fractionated rocks (all types of mangerite, charnockite and syenite) includes as felsic minerals alkali feldspar (often densely perthitic) predominant over sodic oligoclase $\left(\mathrm{An}_{20-22}\right)$ and quartz. The mafics are orthopyroxene and clinopyroxene, both exhibiting abundant exsolution lamellae and strongly iron-rich compositions (Janasi 1996); the orthopyroxene seems to correspond to inverted pigeonite (Choudhuri \& lyer 1996). Hastingsitic hornblende coexists with the pyroxenes or may replace them totally in more retrogressed varieties. Accessories include Fe-Ti oxides (ilmenite and magnetite), apatite, abundant prismatic zircon and traces of brownish allanite.

The more fractionated hololeucocratic pink granites are rich in quartz which usually defines a strong stretching lineation; perthitic microcline and sodic oligoclase usually coexist, but some alaskites have mesoperthite as the sole feldspar. Hastingsitic hornblende is the main mafic mineral, in part replaced by brown and/or greenish biotite. Accessories are the same as in the mangerites. although much less abundant; an exception is allanite, present as larger, orange-colored euhedral crystals.

The Pinhal-type granites Migmatites are abundant in the central and southern portion of northern segment of the SGTN. The gneissic portions are mostly orthoderived, and their compositions include dark (clinopyroxene-biotite)hornblende diorite, greyish (hornblende)-biotite tonalite and light gray to pink biotite granite. The leucosome is typically a pink equigranular medium-grained biotite granite and may form concordant centimetric layers or discordant veins and small irregular bodies. The Pinhal-type granites are texturally identical to these leucosomes, and seem to represent larger intrusive bodies of anatectic material, often with a very irregular shape and difficult to represent even in detailed maps (e.g., Wernick \& Penalva 1980). In most outcrops these granites are quite heterogeneous, exhibiting nebulitic structures, abundant schlieren and gneissic xenoliths. Not rarely, more than one granite facies is present in the same outcrop, for instance a darker inequigranular facies irregularly intruded by a light equigranular one (cf. Haddad et al 1996).

In contrast to the SJRP granitoids, in which they are locally intrusive, the Pinhal-type granites are commonly only slightly 
foliated. Their modal compositions concentrate in the monzogranite field, although some syenogranites are also found, especially among the ligther facies (Haddad et al. 1996). The textures are panxenomorphic, with subhedral to anhedral oligoclase and perthitic microcline plus abundant quartz as felsic and brownish biotite as the sole main mafic mineral. Two main subtypes were recognized by Haddad et al. (1996) in the type area, near the city of Pinhal (São Paulo) on the basis of the accessory mineralogy: the predominant one has titanite and allanite as common accessories, besides Fe-Ti oxides, apatite and zircon; the second subtype lacks the two first minerals and has some systematically different geochemical characteristics (see below).

\section{The Nazaré Paulista-type granites In the}

southernmost portion of the southern segment of the SGTN, metasupracrustals are abundant. The most common rock types are metapelites, represented by (cordierite \pm K-feldspar \pm sillimanite)-garnet-biotite migmatitic gneisses that grade southwards to (sillimanite)-muscovite-biotite schists. Several types of calc-silicatic rocks occur as decimetric bands interleaved with the metapelite sequence, and may predominate over them in some areas. They also include garnet-biotite-rich rocks, which are distinguished from the metapelites by the presence of amphibole and calcic andesine. Except in a lowergrade discontinuous belt next to the southern boundary of the SGTN, these gneisses are strongly migmatitic and exhibit garnet-bearing leucosomes that locally are quite abundant, giving rise to small bodies of a nebulitic garnet-biotite granite, known as the Nazaré Paulista-type granites with reference to the small locality where it occurs as more expressive bodies (Campos Neto et al. 1984, Wernick et al 1987).

The outcrop aspect of the Nazare Paulista granites is rather peculiar owing to the spotted look given by the profusion of centimetric garnet crystals. In every larger outcrop, the granite is seen to be very heterogeneous, with nebulitic and schlieren structures, gneissic xenoliths, and two or more textural varieties with different mafic contents. Two specially attractive road cuts in the Dom Pedro I Highway exhibit another peculiar feature: a hololeucocratic white facies (with euhedral garnet crystals and devoid of biotite) densely veins the predominant greyish garnet-biotite granite; the contacts vary from sharp in one outcrop (point NP-41 in the present work, next to the Nazare Paulista locality) to irregular in the other (point NP-40, near Bom Jesus dos Perdões). The foliation also varies from slight in NP-41 to much more evident in $\mathrm{NP}-40$.

Modally, all the samples studied are monzogranites. Perthitic microcline with well-developed chessboard twinning, oligoclase $\left(\mathrm{An}_{30-25}\right)$ and quartz are the felsic minerals. Garnet is typically xenomorphic and has wide areas of quartz and feldspar inclusions in the predominant biotite-garnet facies. Biotite is brown or reddish-brown; a light green variety replaces garnet along fractures. Muscovite is rare and secondary after the feldspars in most samples; some larger crystals are seen in samples from the NP-41 outcrop. The main accessories are Fe-Ti oxides, apatite, zircon and monazite. The latter is particularly common in some samples, as inclusions in several minerals, as biotite, garnet and oligoclase.

\section{GEOCHEMISTRY Analytical techniques}

Most of the geochemical data presented here were obtained by the author in recent projects and in this case groups of elements were always analyzed by the same techniques in the same laboratories. In a few cases, it was judged necessary to use older data or data obtained by other authors; whenever possible, the analysis of some key elements were repeated in order to check consistency.

All samples were analyzed for major, minor and some trace-elements $(\mathrm{Ba}, \mathrm{Sr}, \mathrm{Zr}, \mathrm{La}, \mathrm{Y}, \mathrm{V})$ by ICP-AES at the
Departamento de Mineralogia e Petrologia, Institute de Geociencias, Universidade de São Paulo, by the author. Glasses produced by fusion of a mixture of $0.25 \mathrm{~g}$ of sample with 0.75 $\mathrm{g}$ flux (lithium metaborate + tetraborate) were dissolved in 0.2 $\mathrm{N} \mathrm{HNO}_{3}$ and analyzed in an ARL-3410 sequential spectrometer. Details of sample preparation, calibration and drift corrections applied are given in Janasi et al. (1995).

Rare-earth elements were analyzed by different techniques. Three previously analyzed samples taken from Janasi (1996) (CA1232, CA205, CA156) were analyzed by ICPAES at Geolab, in Belo Horizonte, MG, following the methods described by Dutra (1989). Two samples from Nazaré Paulista whose results were kindly provided by Diana Rigatky and Colombo Tassinari were analyzed at ACTLABS, Ancaster, Canada, by ICP-MS (NP32, CT14a); the remaining samples were analyzed by INAA also at ACTLABS. The elements U, Th, Cs, Sc, Hf and Ta were also analyzed by INAA at ACTLABS, except the two samples from the Nazare Paulista granite cited above, in which they were analyzed by ICP-MS.

$\mathrm{Rb}$ was analyzed by X-ray Fluorescence at Cepegeo Centre de Pesquisas Geocronológicas, Institute de Geociências, Universidade de São Paulo.

Choice Of samples Table 1 presents the results of analyses of selected samples from the studied granitoids. From the São José do Rio Pardo suite, for which a larger dataset is available, exclusively mangerites, fine-grained charnockites and granites (both hornblende granites and hololeucocratic granites) were selected. The samples come from different massifs; one sample in each group is from the São Pedro de Caldas massif, studied in detail by the author (Janasi 1996); the remaining as yet unpublished data are from the neighbourhood of the São José do Rio Pardo town (São José do Rio Pardo, Euclides da Cunha, Divinolândia and Campestrinho massifs, Fig. 1).

Five samples of Pinhal-type granite are from the PinhalIpuiuna region, and are taken from Haddad et al. (1996); two other analyses, from the Caldas region, are the author's previously unpublished data.

Ten analysis of the Nazaré Paulista granite are presented, all from the type-area near the localities of Nazaré Paulista and Bom Jesus dos Perdoes. Six of these analysis were done in powdered samples previously analyzed for $\mathrm{Rb}$ and $\mathrm{Sr}$ isotopes by Tassinari (1988) and kinndly supplied by C.G. Tassinari. Unfortunately, no slices of the original samples could be found for petrographic examination; nevertheless, it was judged useful to analyze these samples because of the general lack of good-quality geochemical data on these granites and also as an aid to the interpretation of their isotope signatures (D. Rigatky, in preparation). Four other samples come from the two main roadcuts of the Nazaré Paulista-type granites previously cited: in both outcrops, one analysis refers to the main greyish garnet-biotite granite (NP40a and NP41a) and the other to the hololeucocratic veins of white garnetbearing granite (NP40e and NP41b).

A few other analyses of the studied granites are available in the literature. I have chosen not to use them because it was felt that this could result in some unnecessary noise in the patterns, mostly in view of the wide variety of laboratories and techniques utilized.

The major elements Some of the main distintive chemical aspects of the granites studied can be appreciated in simple binary variation diagrams using $\mathrm{SiO}_{2}$ as a discrimination index. The SJRP suite spans a wide silica range, as the low-quartz mangerites have down to 55-60 wt $\% \mathrm{SiO}_{2}$; the granites S.S. from the three granite types concentrate in the range $70-75 \mathrm{wt} \% \mathrm{SiO}_{2}$. 
Fig. 2a shows clearly the strong contrast in terms of $\mathbf{m g \#}$ $[\mathrm{Mg} /(\mathrm{Mg}+\mathrm{Fe}$ total); cationic proportions] between the three groups. Low mg\# is one of the features considered typical of the SJRP suite in all geochemical work presented previously (Campos Neto et al. 1988, Janasi 1996). The scatter within the suite results from the samples coming from several different massifs; when single massifs or single intrusions within the same massif are considered, it is much less pronounced (Janasi 1995, 1996). The lowest values of mg\# are obtained in the eastern sector of the São Pedro de Caldas massif (here represented by sample CA-1232), where the values are invariably below 10 (Janasi 1996). Unsuspectedly high mg\# for a peraluminous granite ( 30 to more than 40 ) are shown by the Nazaré Paulista samples; in both cases where pairs garnetbiotite granite / hololeucocratic garnet-bearing granite were analyzed, the latter has slightly lower mg\#. The Pinhal-type granites have mg\# intermediate between the two other types, usually in the range 20-30; among these granites, the acessory-poor subtype (Haddad et al 1996, see above) has discernibly higher mg\#.

Higher $\mathrm{Al}_{2} \mathrm{O}_{3}$ and $\mathrm{CaO}$ also differentiate the Nazaré Paulista granites from the other types (Fig. 2b,c); the first reflects their typically peraluminous character, as also does their $\mathrm{A} / \mathrm{CNK}$ ratios, ranging between 1.05 and 1.11 . The reasons for the higher $\mathrm{Ca}$ contents in these granites are less obvious, although somewhat predictable from the more calcic character of their plagioclase. The Ca contents of both remaining types are low when compared with other granite types, e.g. associated calc-alkaline suites (e.g., Janasi 1996, Haddad et al. 1996), which further emphasizes the contrast.



One should notice that the subtype of Pinhal granites poor in accessory minerals tends to deviate towards the Nazaré Paulista granites in the $\mathrm{CaO}$, mg\# and some other variation diagrams.

The $\mathrm{K} / \mathrm{Na}$ ratio (Fig. 2d) rises steadily with fractionation in the SJRP suite. The more differentiated terms grossly overlap with the field occupied by the Pinhal granites. The Nazare Paulista granites have the lowest $\mathrm{K} / \mathrm{Na}$ ratios. In every case where a pair darker/lighter granite from the same outcrop was analyzed (outcrops NP40 and NP41 in Nazaré Paulista and SC77 in Pinhal), the ligther facies was found to exhibit a sensibly higher K/Na ratio (Table 1, Fig. 2d). In this and many other diagrams, sample NP26c is displaced from other Nazaré Paulista granites; in general terms, these features seem to be compatible with the presence of some extra amount of mafic minerals (biotite + some accessories) perhaps incorporated as restitic/schlieren material, which cannot be confirmed by petrography since no slices of the sample could be examined, as explained above.

$\mathbf{R b}, \mathrm{Sr}$ and Ba The behaviour of the elements present mostly in the feldspars and micas is shown in Figure 3. Low $\mathrm{Rb}$ and $\mathrm{Sr}$ contents and consequently high $\mathrm{K} / \mathrm{Rb}$ and $\mathrm{Ba} / \mathrm{Sr}$ typify the SJRP suite. That is especially evident in the set of fine-grained charnockites that have very low $\mathrm{Rb}$ contents (less than $100 \mathrm{ppm}$ ) in spite of their relatively fractionated character $\left(>65 \mathrm{wt} \% \mathrm{SiO}_{2}\right)$.

The higher $\mathrm{Rb}$ contents (usually 200-250 ppm) are shown by the Pinhal granites; Sr accompanies the higher Ca contents in the Nazaré Paulista granites and is thus slightly higher than that of granites with similar $\mathrm{SiO}_{2}$ of the other types; conse-

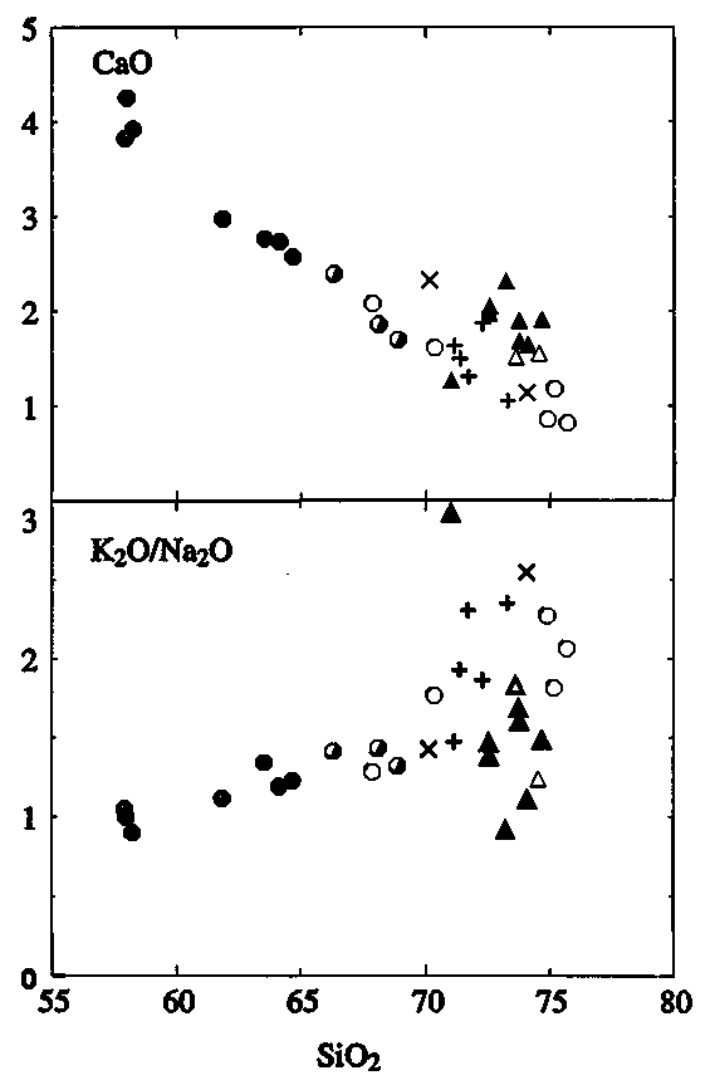

Figure 2 - Binary geochemical variation diagrams: major elements versus SiO2. Symbols: circles: SJRP suite (with grey fill, mangerites; half-filled, charnockites; open, granites); "+"and "x", Pinhal-type granites (" $x$ ", accessory-minerals poor variety); triangles: Nazaré Paulista-type granites (closed, grey garnet-biotite granite; open, hololeucocratic garnet-bearing -white granite). Figura 2 - Diagramas binaries de variação geoquímica: elementos maiores versus $\mathrm{SiO}_{2}$. Simbolos: círculos: suíte SJRP (com preenchimento cinza, mangeritos; com preenchimento parcial cinza, charnockitos; vazios, granitos); "+" e "x", granitos tipo Pinhal (x, variedade pobre em acessórios); triângulos: granitos tipo Nazaré Paulista (cheios: granada-biotita granito cinza; vazios: granito branco hololeucocrático com granada). 


\begin{tabular}{|c|c|c|c|c|c|c|c|c|c|c|c|c|c|c|c|}
\hline \multirow{4}{*}{$\begin{array}{c}\text { sample } \\
\text { massif } \\
\text { sheet }\end{array}$} & \multicolumn{7}{|c|}{ mangerite } & \multicolumn{3}{|c|}{ charnockites } & \multicolumn{5}{|c|}{ granite } \\
\hline & VRP32 & VRP29 & VRP41 & VRP44 & VRP42a & $\mathrm{CA} 1232$ & VRP46a & CA205 & VRP18 & VRP20 & VRP42b & CA 136a & VRPO9 & VRP05 & CA156 \\
\hline & Camp. & Camp. & Divinol. & Divinol. & Divinol. & SPCald. & SJRP & SPCald. & Mococa & Mococa & Divinol. & SPCald. & E.Cunha & E.Cunha & SPCald. \\
\hline & Caconde & Caconde & SJRP & SJRP & SJRP & R.Capiv. & SJRP & Caldas & Guaran. & Guaran. & SJRP & Caldas & SJRP & SJRP & Botelhos \\
\hline $\mathrm{UTM}(\mathbf{k m N})$ & 759560 & 759675 & 760400 & 760620 & 760445 & 758785 & 760800 & 758970 & 762275 & 762235 & 760445 & 759385 & 761025 & 761165 & 759480 \\
\hline $\operatorname{UTM}(\mathrm{kmE})$ & 33020 & 32940 & 31620 & 31370 & 31690 & 37240 & 30490 & 37010 & 30340 & 30715 & 31690 & 35470 & 29945 & 29690 & 35920 \\
\hline $\mathrm{SiO}_{2}$ & 57.94 & 58.31 & 63.99 & 64.05 & 61.30 & 63.76 & 57.92 & 66.03 & 66.71 & 68.54 & 67.35 & 69.34 & 73.96 & 76.61 & 74.17 \\
\hline $\mathrm{TiO}_{2}$ & 1.01 & 1.34 & 0.92 & 0.87 & 1.19 & 0.66 & 1.69 & 0.72 & 0.56 & 0.52 & 0.74 & 0.50 & 0.28 & 0.27 & 0.23 \\
\hline $\mathrm{Al}_{2} \mathrm{O}_{3}$ & 17.43 & 15.56 & 15.19 & 15.39 & 15.80 & 15.82 & 14.99 & 14.10 & 14.69 & 14.77 & 14.90 & 13.95 & 12.51 & 12.37 & 12.55 \\
\hline $\mathrm{Fe}_{2} \mathrm{O}_{3}$ & 2.43 & 3.16 & 1.98 & 1.74 & 2.24 & 2.14 & 2.98 & 2.04 & 1.30 & 1.26 & 1.33 & 1.13 & 0.72 & 0.70 & 0.67 \\
\hline $\mathrm{FeO}$ & 5.10 & 6.63 & 4.16 & 3.66 & 4.71 & 4.50 & 6.25 & 4.28 & 2.73 & 2.65 & 2.80 & 2.37 & I.51 & 1.46 & 1.41 \\
\hline $\mathrm{MnO}$ & 0.24 & 0.25 & 0.13 & 0.13 & 0.16 & 0.20 & 0.18 & 0.17 & 0.09 & & 0.11 & 0.09 & 0.04 & 0.03 & 0.05 \\
\hline MgO & 1.21 & 1.14 & 0.84 & 0.73 & 1.07 & 0.32 & 1.86 & 0.46 & 0.46 & 0.38 & 0.80 & 0.25 & 0.16 & 0.09 & 0.12 \\
\hline $\mathrm{CaO}$ & 3.90 & 3.85 & 2.73 & 2.55 & 2.95 & 2.78 & 4.25 & 2.38 & 1.82 & 1.69 & 2.06 & 1.59 & 1.16 & 0.83 & 0.85 \\
\hline $\mathrm{Na}_{2} \mathrm{O}$ & 4.88 & 4.47 & 4.13 & 4.13 & 4.13 & 4.04 & 4.20 & 3.61 & 3.75 & 3.94 & 3.75 & 3,23 & 2.78 & 2.83 & 2.68 \\
\hline $\mathrm{K}_{2} \mathrm{O}$ & 4.39 & 4.68 & 4.91 & 5.07 & 4.61 & 5.42 & 4.18 & 5.09 & 5.37 & 5.19 & 4.79 & 5.70 & 5.04 & 5.84 & 6.09 \\
\hline $\mathrm{P}_{2} \mathrm{O}_{5}$ & 0.37 & 0.53 & 0.30 & 0.30 & 0.43 & 0.20 & 0.68 & 0.20 & 0.15 & 0.14 & 0.28 & 0.14 & 0.05 & 0.03 & 0.05 \\
\hline Total & 98.90 & 99.91 & 99.29 & 98.62 & 98.60 & 99.84 & 99.17 & 99.07 & 97.63 & 99.19 & 98.91 & 98.30 & 98.21 & 101.06 & 98.87 \\
\hline $\mathbf{R b}$ & 88 & 75 & & 105 & 79 & 126 & 74 & 84 & 88 & 81 & 95 & 148 & 122 & 141 & 163 \\
\hline $\mathrm{Ba}$ & 2120 & 1947 & 1644 & 1645 & 1776 & 1761 & 1778 & 1830 & 1229 & 1177 & 1301 & 1106 & 647 & 763 & 388 \\
\hline $\mathrm{Sr}$ & 393 & 310 & 275 & 283 & 305 & 189 & 355 & 187 & 182 & 144 & 257 & 147 & 119 & 136 & 80 \\
\hline $\mathrm{Cs}$ & & $<0.5$ & & 0.6 & & $<0.5$ & $<0.5$ & $<0.5$ & & $<0.5$ & $<0.5$ & 0.9 & 0.6 & 0.5 & $<0.5$ \\
\hline v & & & & & & & 69 & 15 & & & & & & & \\
\hline $\mathrm{Sc}$ & & 20.1 & & 8.7 & & 14.0 & 14.8 & 15.9 & & 7.6 & 6.1 & 6.4 & 3.8 & 1.8 & $<0.5$ \\
\hline Ta & & 1.4 & & 1.5 & & 1.4 & 2.1 & 1.1 & & $<0.5$ & 1.0 & 1.7 & $<0.5$ & $<0.5$ & $<0.5$ \\
\hline Hf & & 21.2 & & 14.8 & & 18.70 & 14.70 & 17.4 & & 12.0 & 9.4 & 14.2 & 10.1 & 8.0 & 18.7 \\
\hline $\mathrm{Zr}$ & 993 & 1142 & 675 & 740 & 867 & 1056 & 623 & 960 & 638 & 600 & 429 & 628 & 338 & 256 & 288 \\
\hline $\mathbf{Y}$ & 33 & 46 & 37 & 26 & 40 & 47 & 50 & 65 & 9 & 5 & 11 & 48 & 31 & & 41 \\
\hline Th & & 1.8 & & 1.6 & & 2.5 & 2.0 & 1.0 & & 1.1 & 1.2 & 7.8 & 16.7 & 9.5 & 22.5 \\
\hline U & & $<0.2$ & & 0.7 & & $<0.2$ & $<0.2$ & 0.2 & & $<0.2$ & $<0.2$ & $<0.2$ & 0.8 & $<0.2$ & $<0.2$ \\
\hline La & & 52 & & 54.3 & & 30.71 & 75 & 33.4 & 41 & 30.3 & 43.5 & 57.7 & 151 & 102 & 152.2 \\
\hline $\mathrm{Ce}$ & & 110 & & 103 & & 81.85 & 148 & 78.4 & & 59 & 83 & 126 & 290 & 168 & 316.5 \\
\hline $\mathrm{Nd}$ & & 53 & & 50 & & 47.72 & 69 & 42.1 & & 31 & 37 & 61 & 116 & 53 & 118.8 \\
\hline $\mathrm{Sm}$ & & 10.9 & & 7.75 & & 10.53 & 12.3 & 8.9 & & 5.01 & 5.9 & 11.3 & 17.4 & 5.51 & 17.83 \\
\hline Eu & & 5.07 & & 3.36 & & 3.69 & 3.7 & 3.79 & & 2.91 & 2.67 & 2.53 & 1.76 & 1.5 & 1.7 \\
\hline Gd & & & & & & 8.47 & & 7.19 & & 4.4 & & & & & 10.08 \\
\hline $\mathrm{Tb}$ & & 1.5 & & 1.0 & & & 1.60 & & & 0.6 & 0.7 & 1.6 & 1.8 & $<0.5$ & \\
\hline Dy & & & & & & 7.95 & & 7.11 & & & & & & & 5.75 \\
\hline Ho & & & & & & 1.61 & & & & & & & & & 1.13 \\
\hline $\mathrm{Er}$ & & & & & & 4.41 & & 4.17 & & & & & & & 2.95 \\
\hline $\mathrm{Tm}$ & & & & & & & & 0.00 & & & & & & & \\
\hline Yb & & 4.06 & & 2.26 & & 4.07 & 3.90 & 4.08 & & 1.83 & 1.64 & 4.29 & 1.89 & 0.62 & 2.09 \\
\hline Lu & & 0.62 & & 0.34 & & 0.56 & 0.62 & 0.59 & & 0.28 & 0.25 & 0.62 & 0.29 & 0.10 & 0.31 \\
\hline $\mathbf{m g} \#$ & 22.83 & 17.67 & 20.11 & 19.93 & 22.08 & 8.15 & 27.08 & 11.83 & 17.38 & 15.16 & 26.30 & 11.61 & 11.66 & 7.13 & 9.59 \\
\hline A/CNK & 0.88 & 0.80 & 0.89 & 0.91 & 0.92 & 0.90 & 0.78 & 0.89 & 0.96 & 0.97 & 0.99 & 0.97 & 1.03 & 0.99 & 1,00 \\
\hline $\mathrm{La} / \mathrm{Yb}$ & & 8.6 & & 16.2 & & 5.1 & 13.0 & 5.5 & & 11.2 & 17.9 & 9.1 & 53.9 & 111.0 & 49.1 \\
\hline $\mathrm{K} / \mathrm{Rb}$ & 414 & 518 & & 401 & 484 & 357 & 469 & 503 & 507 & 532 & 419 & 320 & 343 & 344 & 310 \\
\hline
\end{tabular}

- UTM (km N, E): sample location in the UTM reference; sheet: topographic 1:50,000 sheet where the sample is located; massif: name of the occurrence (see Fig. I). Major elements in weight percent; trace-elements in ppm.

- UTM (km N,E): localização peso; elementos traço em ppm. 


\begin{tabular}{|c|c|c|c|c|c|c|c|c|c|c|c|c|c|c|c|c|c|}
\hline \multirow[b]{2}{*}{ sample } & \multicolumn{7}{|c|}{ granito Pinhal } & \multicolumn{10}{|c|}{ granito Nazaré } \\
\hline & PH182a & PH12c & $\mathrm{PH} 200$ & SC77B & SC77A & $\mathrm{CA} 200$ & CA-270 & NP26b & NP26c & NP32 & CT14a & CT15a & CT15b & NP40a & NP40e & NP41a & NP4lb \\
\hline massif & Pinhal & Pinhal & Pinhal & SRCald. & SRCald. & Caldas & Caldas & NPaul & NPaul & NPaul & NPaul & NPaul & NPaul & NPaul & NPaul & NPaul & NPaul \\
\hline sheet & Pinhal & Pinhal & Pinhal & SRCald. & SRCald. & & R.Capiv. & Piracaia & Piracaia & Piracaia & Piracaia & Piracaia & Piracaia & Piracaia & Piracaia & Piracaia & Piracaia \\
\hline UTM $(\mathbf{k m N})$ & 753940 & 754650 & 754340 & 756365 & 756365 & & 758840 & 743960 & 743960 & 744290 & 743683 & 743683 & 743683 & 743780 & 743780 & 743683 & 743683 \\
\hline UTM(kmE) & 32175 & 33660 & 33575 & 36535 & 36535 & & 37930 & 35435 & 35435 & 35420 & 35779 & 35779 & 35779 & 35152 & 35152 & 35779 & 35779 \\
\hline $\mathrm{SiO}_{2}$ & 70.42 & 69.64 & 70.46 & 69.69 & 73.29 & 70.21 & 72.92 & 71.42 & 70.05 & $\overline{72.41}$ & 73.57 & 71.18 & 72.14 & 73.48 & 73.56 & 73.33 & 72.48 \\
\hline $\mathrm{TiO}_{2}$ & 0.33 & 0.41 & 0.51 & 0.47 & 0.20 & 0.47 & 0.37 & 0.13 & 0.64 & 0.20 & 0.21 & 0.31 & 0.30 & 0.18 & 0.06 & 0.20 & 0.12 \\
\hline $\mathrm{Al}_{2} \mathrm{O}_{3}$ & 13.56 & 13.20 & 13.86 & 14.41 & 13.24 & 14.25 & 13.27 & 14.10 & 13.86 & 14.61 & 13.92 & 14.63 & 14.77 & 14.43 & 14.49 & 14.21 & 14.26 \\
\hline $\mathrm{Fe}_{2} \mathrm{O}_{3}$ & 0.84 & 0.89 & 0.80 & 1.04 & 0.56 & 0.82 & 0.78 & 0.26 & 0.93 & 0.47 & 0.27 & 0.52 & 0.53 & 0.36 & 0.17 & 0.52 & 0.50 \\
\hline $\mathrm{FeO}$ & 1.76 & 1.86 & 1.69 & 2.18 & 1.18 & 1.71 & 1.64 & 0.54 & 1.96 & 0.98 & 0.56 & 1.08 & 1.11 & 0.75 & 0.35 & 1.09 & 1.05 \\
\hline $\mathrm{MnO}$ & 0.08 & 0.06 & 0.09 & 0.08 & 0.05 & 0.05 & 0.05 & 0.02 & 0.01 & 0.02 & 0.00 & 0.02 & 0.02 & 0.00 & 0.02 & 0.04 & 0.04 \\
\hline $\mathrm{MgO}$ & 0.58 & 0.45 & 0.55 & 1.08 & 0.38 & 0.56 & 0.35 & 0.21 & 1.13 & 0.59 & 0.30 & 0.48 & 0.50 & 0.32 & 0.11 & 0.46 & 0.37 \\
\hline $\mathrm{CaO}$ & 1.82 & 1.27 & 1.48 & 2.31 & 1.13 & 1.61 & 1.05 & 1.84 & 1.25 & 2.29 & 1.88 & 2,01 & 1.96 & 1.63 & 1.53 & 1.67 & 1.49 \\
\hline $\mathrm{Na}_{2} \mathrm{O}$ & 2.72 & 2.74 & 3.08 & 3.17 & 2.46 & 3.51 & 2.63 & 3.04 & 2.17 & 3.76 & 3.11 & 3.26 & 3.22 & 3.75 & 3.72 & 2.97 & 2.82 \\
\hline $\mathrm{K}_{2} \mathrm{O}$ & 5.06 & 6.32 & 5.94 & 4.52 & 6.26 & 5.17 & 6.18 & 5.12 & 6.33 & $\mathbf{3 . 4 4}$ & 4.61 & 4.49 & 4.72 & 4.14 & 4.60 & 4.75 & 5.15 \\
\hline $\mathrm{P}_{2} \mathrm{O}_{5}$ & 0.08 & 0.08 & 0.08 & 0.17 & 0.06 & 0.15 & 0.08 & 0.10 & 0.10 & 0.02 & 0.02 & 0.00 & 0.05 & 0.03 & 0.04 & 0.04 & 0.05 \\
\hline P.F. & 0.56 & 0.55 & 0.34 & 0.54 & 0.78 & 0.49 & & & & & & & & & & & \\
\hline Total & 97.80 & 97.47 & 98.88 & 99.66 & 99.59 & 99.00 & 99.32 & 96.78 & 98.43 & 98.78 & 98.46 & 97.99 & 99.33 & 99.08 & 98.64 & 99.28 & 98.32 \\
\hline $\mathrm{Cr}$ & 9 & 2 & 10 & 7 & 10 & 14 & & & & 23 & 14 & & & & & & \\
\hline $\mathrm{Ni}$ & 23 & 23 & 10 & 10 & 10 & & & & & 6 & & & & & & & \\
\hline $\mathrm{Sc}$ & 3.2 & 2.7 & & 4.8 & & 2.7 & 1.8 & & & & & & & & & & \\
\hline $\mathrm{v}$ & 23 & 26 & 23 & 45 & 28 & & 15 & & 52 & 10 & 9 & & & & & & \\
\hline $\mathbf{R b}$ & 222 & 203 & 210 & 209 & 227 & 239 & 213 & 138 & 213 & 109 & 143 & 140 & 148 & & & & \\
\hline Cs & 1.6 & 1.6 & & 3.0 & & 1.8 & & & & 0.8 & 1.6 & & & & & & \\
\hline $\mathrm{Ba}$ & 1367 & 896 & 644 & 873 & 873 & 1060 & 663 & 1071 & 1972 & 956 & 746 & 846 & 846 & 906 & 863 & 859 & 918 \\
\hline $\mathrm{Sr}$ & 339 & 306 & 246 & 257 & 211 & 200 & 116 & 303 & 436 & 435 & 318 & 266 & 273 & 326 & 314 & 267 & 268 \\
\hline $\mathrm{Ta}$ & 1.5 & 0.8 & & 0.8 & & 1.8 & & & & & & & & & & & \\
\hline Hf & 11.3 & 10.5 & & 6.3 & & 9.4 & 9.5 & & & 3.9 & 3.1 & & & & & & \\
\hline $\mathrm{Zr}$ & 263 & 398 & 320 & 198 & 188 & 440 & 288 & 86 & 139 & 108 & 85 & 130 & 135 & 107 & 77 & 121 & 103 \\
\hline $\mathbf{Y}$ & 6 & 27 & 114 & 16 & 6 & & 19 & & & 29 & 2 & & & & & 6 & 9 \\
\hline Th & 17.8 & 23.3 & & 14.7 & & 16.8 & 26.5 & & & 10.12 & 11.41 & & & & & & \\
\hline $\mathbf{U}$ & 1.9 & 1.4 & & 2.2 & & 2.0 & 1.5 & & & 0.99 & 1.09 & & & & & & \\
\hline La & 115.6 & 194 & 86 & 48.4 & 25 & 99 & 130 & 37 & 452 & 42.3 & 31.8 & 52 & 61 & 39 & 18 & 42 & 48 \\
\hline $\mathrm{Ce}$ & 223.1 & 343 & & 97 & & 221 & 267 & & & 53.9 & 57.0 & & & & & & \\
\hline Nd & 62.75 & 112 & & 34 & & 86 & 97 & & & 20.6 & 18.8 & & & & & & \\
\hline $\mathrm{Sm}$ & 7.35 & 12.3 & & 5.2 & & 16.1 & 11.9 & & & 3.4 & 3.3 & & & & & & \\
\hline $\mathrm{Eu}$ & 0.93 & 1.6 & & 1.3 & & 1.74 & 1.5 & & & 1.31 & 1.02 & & & & & & \\
\hline Gd & 3.35 & & & & & & & & & 3.7 & 1.8 & & & & & & \\
\hline $\mathrm{Tb}$ & & 1.3 & & 0.7 & & 1.7 & 1.0 & & & 0.6 & 0.2 & & & & & & \\
\hline Dy & 1.52 & & & & & & & & & 3.6 & & & & & & & \\
\hline Ho & 0.27 & & & & & & & & & 0.7 & & & & & & & \\
\hline Er & 0.59 & & & & & & & & & 2.0 & 0.1 & & & & & & \\
\hline $\mathrm{Tm}$ & & & & & & & & & & 0.25 & & & & & & & \\
\hline $\mathrm{Yb}$ & 0.39 & 2.60 & & 1.30 & & 1.79 & 1.3 & & & 1.3 & 0.2 & & & & & & \\
\hline Lu & 0.08 & 0.35 & & 0.23 & & 0.24 & 0.20 & & & 0.23 & & & & & & & \\
\hline mg \# & 29.16 & 23.14 & 28.90 & 38.20 & 28.70 & 28.96 & 21.05 & 32.60 & & 42.98 & 40.03 & 35.59 & 35.87 & 34.75 & 28.37 & 34.49 & 30.62 \\
\hline A/CNK & 1.02 & 0.97 & 0.98 & 1.01 & 1.03 & 1.00 & 1.03 & 1.02 & 1.09 & 1.04 & 1.03 & 1.05 & 1.06 & 1.06 & 1.04 & 1.09 & 1.10 \\
\hline $\mathrm{La} / \mathrm{Yb}$ & 200 & 50.3 & 235 & 25.1 & 230 & 37.3 & 67.4 & 308 & & 21.9 & $>107$ & 366 & 365 & & & & \\
\hline
\end{tabular}


quently, the Nazaré Paulista granites have the lowest $\mathrm{Ba} / \mathrm{Sr}$ and $\mathrm{Rb} / \mathrm{Sr}$ of all analyzed granites s.s. (Fig. 3b,d).

Zr, La, Th, $\mathbf{U}$ The behaviour of these elements, present mostly in accessory minerals, is shown in Figure 4. Very high $\mathrm{Zr}$ contents, often over $1,000 \mathrm{ppm}$, are a characteristic feature of the mangerites from the SJRP suite, which in part responds for the "intra-plate" geochemical signature attributed to the suite in previous works. It is a direct reflection of the high temperatures of the magmas that originated the suite. The slight and continuous decrease in $\mathrm{Zr}$ contents in the more fractionated samples demonstrates that these magmas were zircon-saturated, and allows liquidus temperatures to be calculated according to the equation of Watson (1988, as quoted in Watt \& Harley 1993); the values obtained fall from over $950^{\circ} \mathrm{C}$ in the more fractionated mangerites to $\mathrm{ca}, 850^{\circ} \mathrm{C}$ in the hololeucocratic granites. The Pinhal-type granites have $\mathrm{Zr}$ contents ranging from 250 to $400 \mathrm{ppm}$, which corresponds to saturation temperatures around $820-870^{\circ} \mathrm{C}$; the two accessory-poor samples have slightly lower $\mathrm{Zr}$ contents (Fig. 4a), which could reflect lower liquidus temperatures or a $\mathrm{Zr}$ insaturated character (see below). The Nazaré Paulista granites derive from lower-temperature magmas, as can be deduced from their lower contents of $\mathrm{Zr}$ and LREE. The gentle fall of the $\mathrm{Zr}$ and La contents with differentiation suggests that these magmas were zircon and monazite-saturated, and essentially concordant zircon and monazite saturation temperatures (respectively, $730-780^{\circ} \mathrm{C}$ and $750-760^{\circ} \mathrm{C}$ ) are obtained from the formulations of Watson $(1988$, apud Watt \& Harley 1993) and Montel (1993).

Th and U contents are extremely low, the latter often below detection limits $(<0.2 \mathrm{ppm})$ in the mangerites and char-
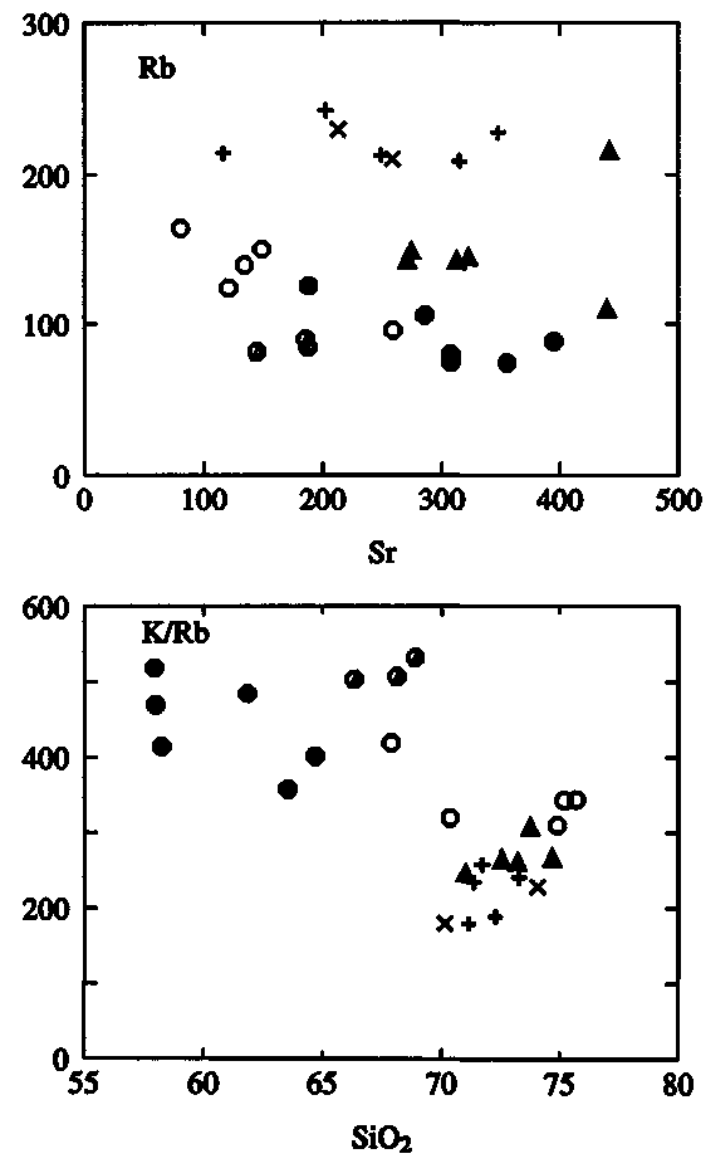

nockites of the SJRP suite, and this is taken as evidence of the derivation of their parent melts from depleted granulite sources (Janasi, 1996). The granitic rocks analyzed have contents of both elements about 1 order of magnitude higher (10-20 ppm Th; 1-2 ppm U). The much higher Th (and La) contents observed in the hololeucocratic granites as compared to the less fractionated rocks of the SJRP suite was discussed by Janasi (1996) and taken as an evidence that simple closedsystem crystal fractionation does not respond satisfactorily for the evolution of the last differentiates of the suite. Although the number of analyses is still too low, it seems that the Nazaré Paulista granites are slightly poorer in Th and U as compared to the Pinhal granites (Fig. 4b,d). The sample of accessory-poor Pinhal granite $\mathrm{SC} 77 \mathrm{~b}$ differs from the remaining Pinhal-type granites because of its higher U/Th ratio.

Rare-earth elements Rare-earth element patterns normalized to chondritic values of Boynton (1984) are shown in figure 5 .

The Pinhal granites exhibit fractionated patterns $(\mathrm{La} / \mathrm{Yb}) \mathrm{N}$ $=40-50$ with pronounced negative Eu anomalies; the accessory-poor sample SC77b has a less fractionated pattern and a very weak negative Eu anomaly (Fig. 5a).

The two analyzed samples of Nazaré Paulista granite have quite contrasted REE patterns (Fig. 5b). One of the samples (NP32) is slightly fracionated, with $(\mathrm{La} / \mathrm{Yb}) \mathrm{N}=15$, while the other is extremely depleted in HREE, with contents of elements heavier than Dy lower than both detection limits and the chondritic values. Both differ from the Pinhal granites by the lower REE contents and by the presence of slightly positive Eu anomalies. The latter seems consistent with the high $\mathrm{Ca}$ and Sr contents of these samples (see below), but it must
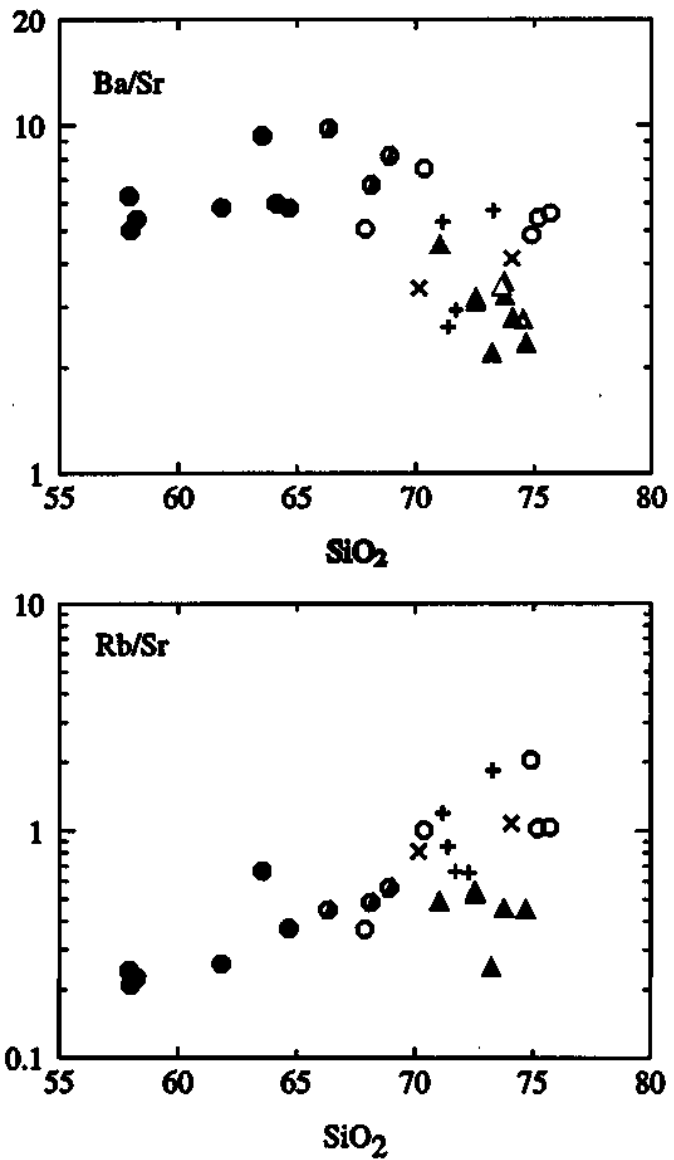

Figure 3 - Binary geochemical variation diagrams involving $\mathrm{SiO}_{2}, \mathrm{Ba}$, Sr andRb. Symbols as in Figure 2.

Figura 3 - Diagramas binários de variação geoquímica envolvendo $\mathrm{SiO}_{2}$, Ba, Sre Rb. Símbolos como na Figura 2. 

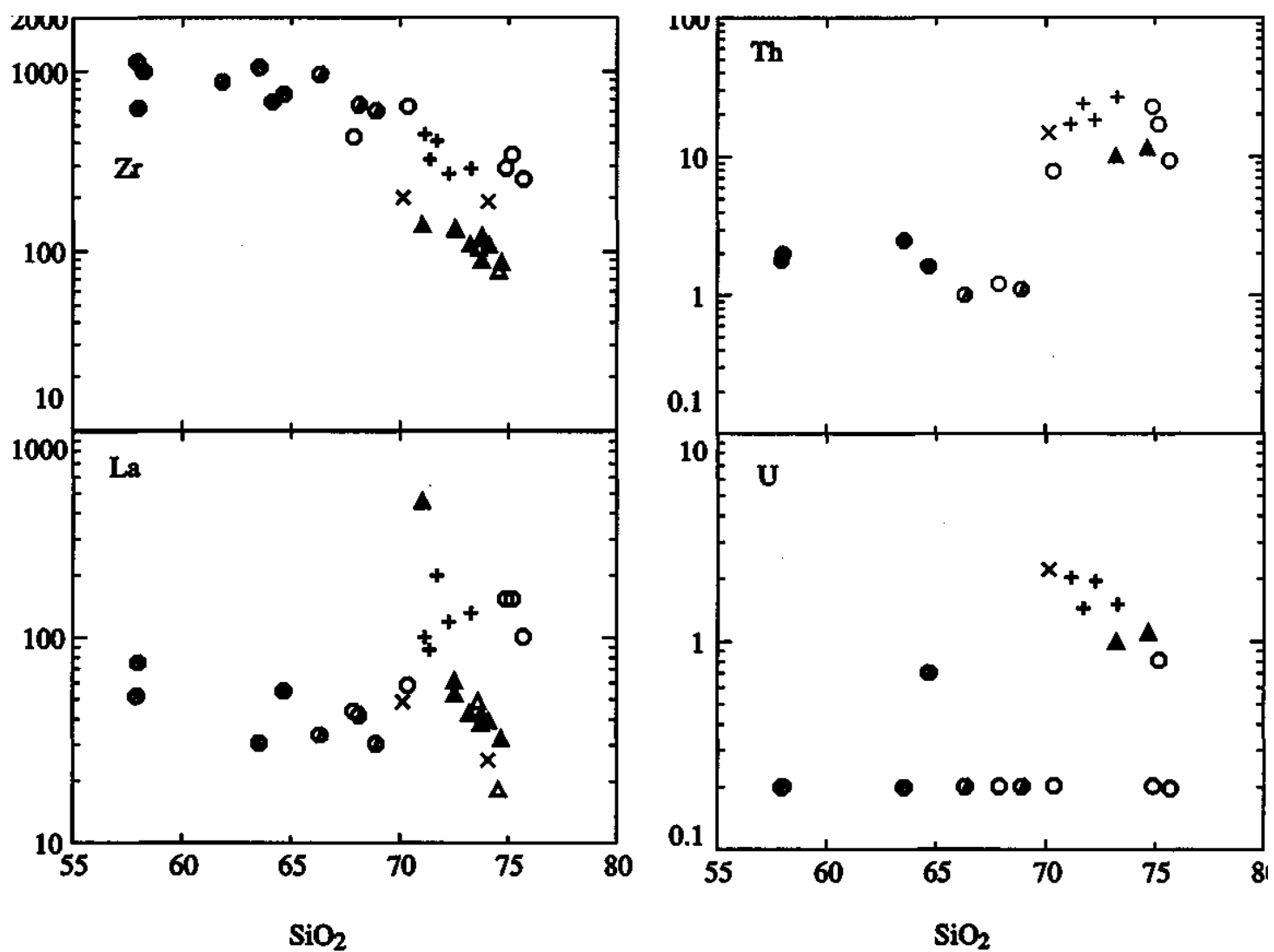

Figure 4 - Binary geochemical variation diagrams: $\mathrm{SiO}_{2}$, versus U, Th, Zr and La. Symbols as in Figure 2.

Figure 4 - Diagramas binários de variações geoquímica: $\mathrm{SiO}_{2}$, versus $\mathrm{U}, \mathrm{Th}, \mathrm{Zr}$ e La. Símbolos como na Figura 2.

be advanced that a positive Eu anomaly seems not to be a characteristic of all Nazaré Paulista granites (C.D. Rigatky, in preparation).

A slightly fractionated REE pattern with a well-defined positive Eu anomaly is characteristic of the mangerites and fine-grained charnockites of the SJRP suite (Fig. 5c; also Janasi 1996). Positive correlations between $\left(\mathrm{Eu} / \mathrm{Eu}^{*}\right) \mathrm{N}$ and the $\mathrm{Al}, \mathrm{Na}, \mathrm{Ba}$ and $\mathrm{Sr}$ contents in many mangerite samples show that part of the chemical differences found in these rocks reflects variations in the amount (and sometimes in the type) of cumulate feldspar (Janasi 1995). On the other hand, it seems that a positive $\mathrm{Eu}$ anomaly can be a primary feature of some magmas that formed the SJRP suite; this is especially apparent in the case of the fine-gralned charnockites, in which the mentioned correlations are not observed. The sample of hornblende granite analyzed (CA136a) has a REE pattern identical to those of the less fractionated rocks, except that it shows a negative Eu anomaly. On the other hand, the hololeucocratic granites have a much steeper REE pattern (with a deeper negative $\mathrm{Eu}$ anomaly), difficult to reconcile with simple models of fractionation from the hornblende granites, as already mentioned. These steep patterns are accompanied by the presence of large and abundant allanite crystals in these rocks; with further fractionation to alaskitic facies the LREE fall rapidly, reflecting allanite extraction, and the patterns tend to a "seagull wing" shape (the author's unpublished data).

A word on isotope geochemistry The isotope geochemistry dataset for the granite suites studied here is still very scanty, and mostly restricted to the Rb-Sr system. An effort to gather additional data on the samples used in this work is presently in course.
The largest amount of data presently available comes from the SJRP suite (Oliveira et al 1986, Campos Neto et al 1988); as already pointed out, disparate isochronic $\mathrm{Rb}-\mathrm{Sr}$ ages were obtained from different sets of data, although values near 650 $\mathrm{Ma}$ are within error of recently obtained U-Pb zircon age. The $\left({ }^{87} \mathrm{Sr} /{ }^{86} \mathrm{Sr}\right)_{620}$ ratios concentrate in the $0.709-0.711$ range, overlapping with values obtained in the few Pinhal-type granites for which $\mathrm{Rb}-\mathrm{Sr}$ data are available (taken from Winters 1981).

The Nazaré Paulista granites have higher and more varied $\left({ }^{87} \mathrm{Sr} /{ }^{86} \mathrm{Sr}\right)_{620}$ ratios $(0,715-0,718$; data from Tassinari 1988), reflecting their derivation from a more radiogenic source and their inhomogeneous nature.

\section{SOURCE AREAS AND CONDITIONS OF MELT- ING The São José do Rio Pardo suite}

Previous work on the geochemistry of the SJRP suite stressed its low $\mathrm{Ca}, \mathrm{Sr}$ and $\mathbf{m g \#}$ and high $\mathrm{Zr}$, which were interpreted as an intra-plate signature (Campos Neto et al. 1988, Janasi 1992). The suite was compared to Emslie's (1991) anorogenic AMCG (anorthosite-mangerite-charnockite-granite) association (e.g., Janasi 1996). The total absence of the basic (anorthosite, troctolite, jotunite etc) members of the above association is however a remarkable feature.

Low contents of radiogenic elements, specifically $\mathrm{Rb}, \mathrm{Th}$, $\mathrm{U}$ and $\mathrm{Cs}$ as well as melt generation at low a $\left(\mathrm{H}_{2} \mathrm{O}\right)$ (as evidenced by the high normative $\mathrm{Or} / \mathrm{Ab}$ proportions and the anhydrous mineralogy of the predominant rock types) imply a residual granulitic source (Janasi 1996). This is also corroborated by the very high magmatic temperatures inferred from zircon saturation thermometry (up to $1,000^{\circ} \mathrm{C}$ ), close to the dry granite solidus (e.g., Holtz \& Johannes 1994).

The low contents of radiogenic minerals and $\mathrm{H}_{2} \mathrm{O}$ is even more salient in the fine-gralned charnockites which appear to 

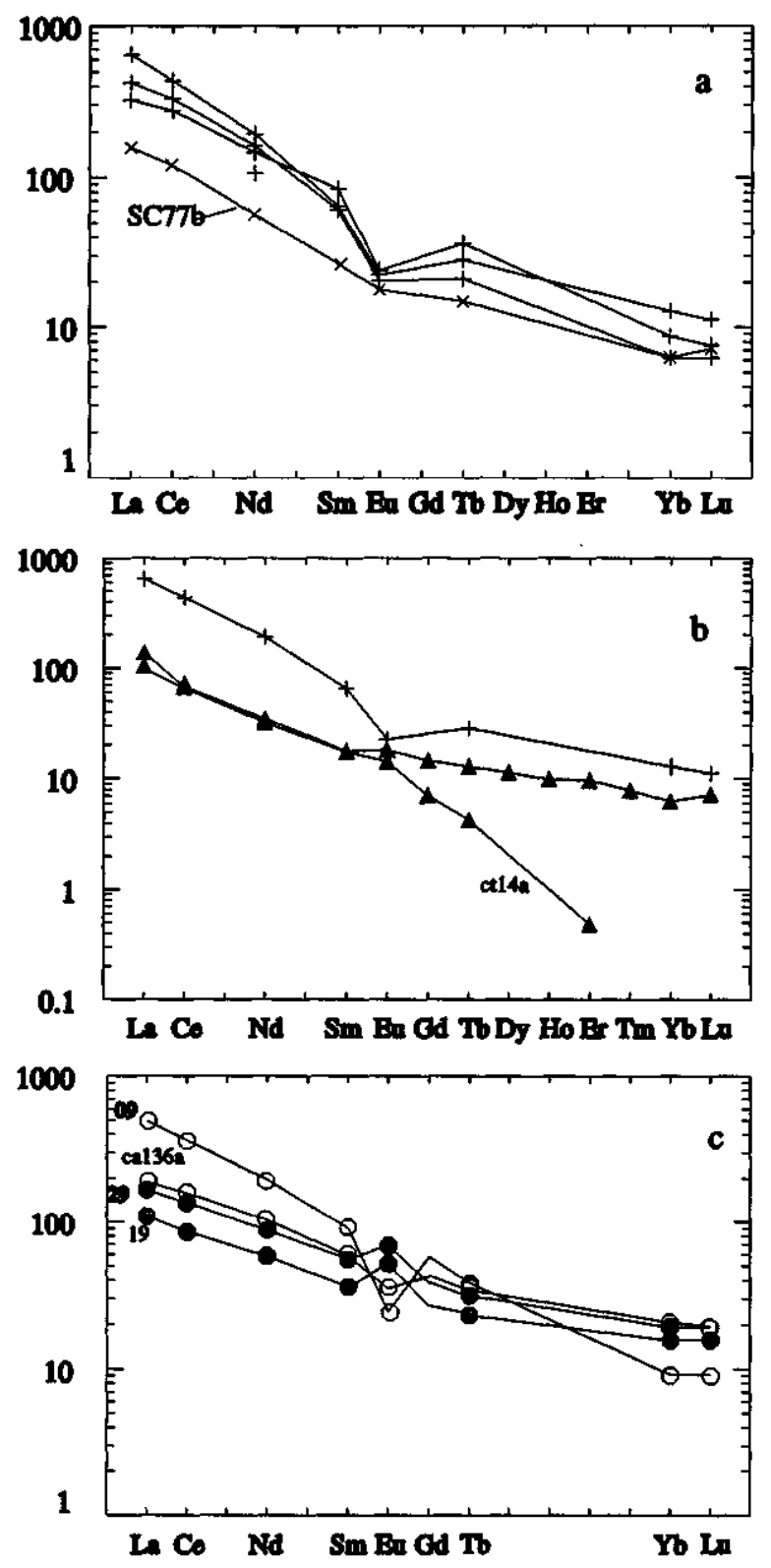

Figure 5 - Rare-earth element patterns normalized to chondrite (Boynton 1984). Symbols as in Figure 2, except for the SJRP suite: circles with black fill, mangerites; grey fill, charnockites; white fill, granites.

Figura 5 - Padrões de elementos terras-raras normalizados pelo condrito (Boynton, 1984). Símbolos como na Figura 2, exceto para a suíte SJRP: círculos com preenchimento preto, mangeritos; cinza, charnockitos; branco, granites.

make a small-volume peculiar group of rocks within the suite. These rocks combine extremely low $\mathrm{Rb}$, Th and high $\mathrm{K} / \mathrm{Rb}$, $\mathrm{Ba} / \mathrm{Sr}$ and $\left(\mathrm{Eu} / \mathrm{Eu}^{*}\right) \mathrm{N}$.The latter ratios reflect the high proportions of $\mathrm{K}$-feldspar in these rocks, and seem to require a source depleted in restitic biotite and also plagioclase. While a virtually biotite-free source is not difficult to envisage at the extreme temperatures in which melting is inferred to have occurred, a plagioclase-poor source seems less probable. The combination of low $\mathrm{Sr}$ and $\mathrm{Ca}$ and a positive Eu anomaly is a common feature in leucosomes of granulite-facies migmatites (e.g., Carrington \& Watt 1995), which is indeed observed in the region (Campos Neto et al. 1996), and seems better explained by disequilibrium melting involving K-feldspar as a reactant phase.
It is generally recognized that disequilibrium melting should be favoured under very low water activities due to the lower rates of dissolution of some accessory minerals and sluggish diffusion of some elements in the residual minerals (e.g., Carrington \& Watt 1995). Indeed, that could also account for the relatively unfractionated REE patterns of the SJRP charnockites and mangerites, if residual garnet was not able to hold the HREE released from zircon dissolution and if the dissolution of an accessory mineral concentrating the LREE was slower than melt extraction (e.g., Sawyer 1991). Concerning the role of garnet, it seems interesting to note that recent REE data indicate that garnets from granulites are typically depleted in HREE when compared to amphibolitegrade garnets (cf. Bea 1996)

The effects of fractional crystallization are very strong in the SJRP suite, and most occurrences correspond to differentiated sill-like bodies generated by in situ fractionation that generated cumulative mangerites and residual granites from a parent melt with quartz mangeritic composition. Details of the geochemical modeling of such process, as well as reasoning for the choice of a quartz mangeritic composition for the parent melts are given in Janasi $(1992,1996)$.

The Pinhal-type granites In contrast to the SJRP suite, the Pinhal-type granites are not depleted in radiogenic elements and have a hydrous mineral (biotite) as the only main mafic. The conjunction of negative Eu anomalies with relatively high $\mathrm{Rb} / \mathrm{Sr}$ and $\mathrm{Ba} / \mathrm{Sr}$ (as compared to the Nazaré Paulista granites) requires a quartz-feldspathic source (tonalitic to granodioritic gnesses) with plagioclase dominant over biotite in the residual assemblage (approaching the "biotitelimited" type of sources of McDermott et al. 1996). As such, although the original source probably was not granulitic, the residuum left after melt extraction might have became so.

The zircon saturation temperatures $\left(800\right.$ to $\left.900^{\circ} \mathrm{C}\right)$ fall within the range expected from experimental studies for biotite dehydration-melting of metaluminous intermediate gneisses (Gardien et al. 1995, Vielzeuf \& Montel 1994) through reactions such as:

Biot $+\mathrm{P} 1+\mathrm{Qtz}=$ melt + Grt \pm Kfs

(e.g., Vielzeuf \& Montel 1994, McDermott et al. 1996). The fractionated REE patterns of most samples can reflect both the retention of HREE by residual garnet and the high proportion of dissolved LREE due to the combination of high temperatures and moderate a $\left(\mathrm{H}_{2} \mathrm{O}\right)$ (increasing both the solubility of LREE-bearing accessory minerals and the diffusion of trace elements in residual phases; cf. for instance Harris et al. 1995).

Within the narrow compositional range shown by the Pinhal-type granites the effects of crystal-melt differentiation are limited. From the petrographical and chemical identity between facies with different mafic contents which appear associated at the outcrop scale, it seems that some differentiation occurred within the suite, although specific work will be necessary to reveal the role played by processes as crystal fractionation and restite unmixing.

The Nazaré Paulista-type granites The lower $\mathrm{Zr}$ and LREE contents of the Nazare Paulista-type granites as compared to the Pinhal-type indicate that they derive from colder magmas ( $\mathrm{Zr}$ saturation temperatures: $730-780^{\circ} \mathrm{C}$; LREE saturation temperatures: $750-760^{\circ} \mathrm{C}$ ). These temperatures are below the range expected for widespread biotite dehydration-melting (e.g., Gardien et al. 1995), and suggest that most of the melting must have occurred through muscovite dehydration-melting (cf. also Harris et al. 1995, McDermott et al. 1996).

The peraluminous character of these granites (with Biot + Grt \pm Sill \pm Musc) and the presence of abundant monazite 
seems to reflect a source with some pelitic component. Such a source, expected to leave a biotite-rich residuum, could also explain the comparatively low $\mathrm{Rb}$ contents (100-150 ppm) typical of all the Nazare Paulista granites studied. Relatively high $\mathrm{Ca}$ and $\mathrm{Sr}$ and possibly also a slightly positive Eu anomaly appears to be a common, though not universal, characteristic of these granites, and may indicate that residual plagioclase is either present in subordinate proportions or is very calcic (since $\mathrm{D}(\mathrm{Sr}, \mathrm{Eu})^{\text {plag/melt }}$ decrease strongly with increasing Ca contents; e.g., Blundy \& Wood 1991).

The only two samples analyzed have disparate REE patterns, and as such a "typical" behavior of these elements in the Nazaré Paulista granites is yet to be determined. The extreme HREE depletion (down to subchondritic contents) of one sample can be attributed to the retention of these elements in residual garnet. The slightly fractionated pattern of the other sample could reflect equally a garnet-free residuum and disequilibrium melting. It must be emphasized that the REE pattern of this sample is much similar to that of sample SC-77b, a representative of the apparently subordinate accessory-poor group of Pinhal-type granites which has many geochemical features reminescent of the Nazaré Paulista types, including lower $\mathrm{Zr}$ and LREE, and higher $\mathrm{Sr}$ and mg\#. The lower $\mathrm{Zr}$ and LREE contents of these samples may indicate lower temperatures of melting, or may reflect some kind of disequilibrium melting; e.g., the rates of melt extraction may have exceeded those of dissolution of zircon and monazite and these accessories could have concentrated in the residuum (cf. Watt \& Harley 1993).

As in the Pinhal-type granites, some effect of crystal-melt segregation is suggested by field, petrographic and chemical data. The pairs of samples from NP-40 and NP-41 are illustrative of these effects (e.g., systematic variations in major and trace elements from the greyish garnet-biotite granites to the white hololeucocratic garnet-bearing granites, apparently compatible with crystal fractionation) and also of the existence of several different parent melts in the suite, as systematic differences between the more primitive facies of the two outcrops are shared by the corresponding more fractionated ones (e.g., K/Na ratios etc, cf. Table 2).

\section{CONCLUDING REMARKS}

The elemental geochemistry of syn-metamorphic granites in the SGTN shows a wide diversity which can be attributed primarily to variations in the protoliths and in the conditions of melting and only secondarily to intra-suite fractionation. The geographical zoning in the distribution of these granites in the terrane follows the exposure of progressively shallower levels of the Neoproterozoic crust from north to south, and testifies to a somewhat limited vertical mobility of their parent magmas: a mangerite-granite suite derived from parental quartz mangeritic magmas generated at high $\mathrm{T}\left(\mathrm{ca} .1000^{\circ} \mathrm{C}\right)$ and $\mathrm{P}(>10$ kbar, Janasi 1992,1996) from depleted granulites is succeded at mid-crustal levels by biotite granites (Pinhal-type) associated to biotite dehydration-melting of tonalitic-granodioritic gneisses at $800-900^{\circ} \mathrm{C}$ and then, at crustal levels in which metasupracrustal rocks begin to predominate over orthogneisses, by garnet-biotite granites (Nazaré Paulista-type) associated to muscovite + biotite dehydration-melting of peraluminous gneisses at $730-780^{\circ} \mathrm{C}$.

The abundance of as yet poorly known muscovite-biotite ( \pm tourmaline, garnet) white granites intruding mica-schists in the southernmost portion of the southern segment of the SGTN (e.g., in the region of Atibaia, Melhem 1995) suggests that the zoning continues to lower-temperature melts very similar to those typically associated with collisional environments (e.g., the Himalayan leucogranites, France-Lanord \& Le Fort, 1988, Harris et al, 1995). South of the SGTN, e.g. in the Embu Domain (Janasi \& Ulbrich, 1985, 1991), synorogenic two-mica leucogranites with a "crustal signature" are quite abundant (Wernick \& Galembeck, 1987), and may also correspond to shallower exposures of products of the same anatectic event (Janasi \& Ulbrich 1991).

Future work should focus on the quantitative determination of pressure, temperature, time and volatile activities of magma generation in the SGTN. Estimates of magma mobility within the crust depend on a much better resolution of the variation of peak metamorphic P and T in the SGTN than presently available. A few attempts at determining P-T-t paths for the metamorphism indicate an almost isothermal decompression (ITD) path typical of collisional orogens (lyer et al 1996). As shown by thermal modelling, temperatures such as those inferred to have been reached in the SGTN lower crust (over $1,000^{\circ} \mathrm{C}$ ) are not attained with simple thickening of continental crust, and incursion of mantle heat (by delamination of the lower crust, decompression of the asthenosphere etc) would be required (Thompson \& Connolly 1995).

A peculiar feature of the SGTN is that a wide range of crustal melts seems to have been generated in a short time interval, probably in response to a single thermal anomaly ascending in the crust. The granite types so produced vary from leucogranites similar to those associated to collisional tectonics to mangerites chemically identical to those found in anorogenic settings. Whereas some kind of relationship with post-collisional extensional tectonics cannot be safely ruled out in the genesis of these granites, the formation of such dissimilar crustal melts under a single tectonic regime emphasizes the fact that the geochemistry of these magmas tells us primarily about their sources and their melting conditions and only indirectly about tectonic environments.

Acknowledgments This work was financed by successive grants from FAPESP, the most recent of which is Proc. 93/3623-3. A.C. Vasconcellos contributed with many ideas regarding granite genesis in the SGTN. The same must be said of Mario Figueiredo, whose continuous encouragement is strongly missed. A critical review by Asit Choudhuri was much appreciated.

\section{REFERENCES}

BASEI, M.A.S.; SIGA JR., O.; SATO, K. \& SPROESSER, W.M. 1995. A metodologia urânio chumbo na Universidade de São Paulo: princípios metodológicos aplicacões e resultados obtidos. Anais da Academia brasileira de Ciências, 67(2): 221-237.

BEA, F. 1996. Residence of REE, Y, Th and U in granites and crustal protoliths; implications for the chemistry of crustal melts. Journal of Petrology, 37(3): 521-552.

BLUNDY, J.D. \& WOOD, B.J. 1991. Crystal-chemical controls on the partitioning of $\mathrm{Sr}$ and $\mathrm{Ba}$ between plagioclase feldspar, silicate melts, and hydrothermal solutions. Geochimica et Cosmochimica Acta, 55. 193-209.

BOYNTON, W.V. 1984. Cosmochemistry of the rare-earth elements: meteorite studies. In: P.Handerson (Ed.): Rare-earth elements geochemistry. Elsevier, Amsterdam, p. 63-114.
CAMPOS NETO, M.C. \& FIGUEIREDO, M.C.H. 1985. Geologia das Folhas São José do Rio Pardo e Guaranésia (porção paulista), 1:50.000. Relatório Final, Institute de Geociências, Universidade de São Paulo, São Paulo, vol. 1,124 pp.

CAMPOS NETO, M.C.; BASEI, M.A.S.; ALVES, F.R. \& VASCONCELLOS, A.C.B.C. 1984. A nappe de cavalgamento de Socorro (SP-MG) In: Congresso Brasileiro de Geologia, 33, Rio de Janeiro. Anais, SBG, 4: $1809-1822$

CAMPOS NETO, M.C; FIGUEIREDO, M.C.H.; JANASI, V.A.; BASEI, M.A.S. \& FRYER, B.J. 1988. The São José do Rio Pardo mangeriticgranitic suite, southeastern Brazil. Geochimica Brasiliensis, 2: 185200.

CAMPOS NETO, M.C.; JANASI, V.A. \& CABY, R. 1996. Ocorrência de granulitos empobrecidos nas porcões basais da Nappe de Empurrão Socorro-Guaxupé. Bol. Inst. Geoc. USP, Série Especial, 18: 11-13. 
CARRINGTON, D.P. \& WATT, G.R. 1995. A geochemical and experimental study of the role of K-feldspar during water-undersaturated melting of metapelites. Chemical Geology, 122: 59-76.

CHOUDHURI, A. \& IYER, S.S. 1996. Piroxênios e o caminhamento P-T na facies granulito do SW de Minas Gerais, Brasil. Boletim IG-USP, Publ. Especial, 18: 7-10.

CLEMENS, J.D. \& VIELZEUF, D. 1987. Constraints on melting and magma production in the crust. Earth and Planetary Science Letters, 86: 287-306.

DUTRA, C.V. 1989. Geoquímica analítica de Elementos Terras RarasAplicaf5o da Espectrometria de Plasma (ICP). In: Formoso, M.L.L.; Nardi, L.V.S. \& Hartmann, L.A. (Eds.): Geoquímica dos Elementos Terras Raras no Brasil, CPRiWDNPM/SBGq, p. 7-13.

EBERT, H.D.; CHEMALE JR., F.; BABINSKI, M; ARTUR, A.C. \& VAN SCHMUS, W.R. 1996. Tectonic setting and U/Pb zircon dating of the plutonic Socorro Complex in the Transpressive Rio Paraíba do Sul Shear Belt, SE Brazil. Tectonics, 15(2): 688-699.

EMSLIE, R.F. 1991. Granitoids of rapakivi granite-anorthosite and related associations. Precambian Research, 51: 173-192

FIGUEIREDO, M.C.H. \& CAMPOS NETO, M.C. 1994. O arco magmático cálcio-alcalino de alto-K da microplaca Apiaí-Guaxupé. In: Congresso Brasileiro de Geologia, 38, Balneário Camboriú-SC, Sociedade Brasileira de Geologia, 1994. Boletim de Resumes Expandidos, 1:620-621.

FRANCE-LANORD, C. \& LE FORT, P. 1988. Crustal melting and granite genesis during the Himalayan collision orogenesis. Transactions of the Royal Society of Edinbourg, 79: 183-195.

GARDEN, V.; THOMPSON, A.B.; GRUJIC, D. \& ULMER, P. 1995 Experimental melting of biotite + plagioclase + quartz \pm muscovite assemblages and implications for crustal melting. Journal of Geophysical Research, 100(B8): 15581-15591.

HADDAD, R.C. 1995. O batólito granitoide Pinhal-Ipuiuna (SP-MG): um exemplo do magmatismo cálcio-alcalino potássico neoproterozóico no sudeste brasileiro. $\mathrm{PhD}$ Thesis, Institute de Geociências, Universidade de São Paulo, 270 pp. (unpublished)

HADDAD, R.C; JANASI, V.A. \& ULBRICH, H.H.G.J. 1996. Caracterização geoquímica preliminar dos granitóides aflorantes nas vizinhancas do Batólito Pinhal-Ipuiuna (SP-MG). Revista Brasileira de Geociências (submetido)

HARRIS, N.; AYRES, M. \& MASSEY, J. 1995. Geochemistry of granitic melts produced during the incongruent melting of muscovite: Implications for the extraction of Himalayan leucogranite magmas. Journal of Geophysical Research, 100(B8): 15767-15777.

HOLTZ, F. \& JOHANNES, W. 1994. Maximum and minimum water contents of granitic melts: implications for chemical and physical properties of ascending magmas. Lithos, 32:149-159.

ICENHOWER, J. \& LONDON, D. 1995. An experimental study of element partitioning among biotite, muscovite, and coexisting peraluminous silicic melt at $200 \mathrm{Mpa}\left(\mathrm{H}_{2} \mathrm{O}\right)$. American Mineralogist, 80:1229-1251.

ICENHOWER, J. \& LONDON, D. 1996. Experimental partitioning of Rb, $\mathrm{Cs}, \mathrm{Sr}$, and $\mathrm{Ba}$ between alkali feldspar and peraluminous melt. American Mineralogist, 81: 719-734.

IYER, S.S.; CHOUDHURI, A.; PATTISON, D.R.M. \& DE PAOLI, G.R 1996. Petrology and geochemistry of the Neoproterozoic Guaxupe granulite facies terrain, southeastern Brazil. Precambrian Research, 77: $23-40$.

JANASI, V.A. 1992. Rochas sieníticas e mangeritico-charnoquiticas neoproterozóicas da região entre Caldas e Campestre, $M G$ : aspectos petrológicos. $\mathrm{PhD}$ Thesis, Institute de Geociências, Universidade de São Paulo, 298 pp. (unpublished).

JANASI, V.A. 1995. Geochemical constraints on the mangerite-"rapakivi" granite connection in the Neoproterozoic São José do Rio Pardo suíte southwestern Brazil. In: Symposium on rapakivi granites and related rocks, Betem, Brazil, 1995. Abstracts vol., p. 42-43.

JANASI, V.A. 1996. Neoproterozoic mangerite-granite magmatism in southeastern Brazil: the São Pedro de Caldas massif. Anais da Academia Brasileira de Ciencias, in press.

JANASI, V.A. \& ULBRICH, H.H.G.J. 1985. Avaliação das informações disponíveis para os granitódes do Estado de São Paulo. In: Simpósio Regional de Geologia, 5, São Paulo. Atas, SBG-NSP, 1:133-146.

JANASI, V.A. \& ULBRICH, H.H.G.J. 1991. Late Proterozoic granitoid magmatism in the State of São Paulo, southeastern Brazil. Precambrian Research, 51: 351-374.

JANASI, V.A. \& INVERNIZZI, A.L. 1996. Diversidade geoquímica de granulitos e charnoquitos da região de Mococa, nordeste do Estado de São Paulo. In: Congresso Brasileiro de Geologia, 39, Salvador, BA. Anais.,6:309-312.

JANASI, V.A.; ANDRADE, S. \& ULBRICH, H.H.G.J. 1996. A correção do drift instrumental em ICP-AES com espectrômetro sequencial e a análise de elementos maiores, menores e traços em rochas. Boletim $I G$-USP (Série Científica), in press.

JOHANNES, W. \& HOLTZ, F. 1990. Formation and composition of $\mathrm{H}_{2} \mathrm{O}-$ undersaturated granitic melts. In: J.R. Ashworth \& M. Brown (Eds.) High-Temperature Metamorphism and Crustal Anatexis. Unwin Hyman, London, pp. 87-104.
McDERMOTT, $\mathrm{F}$; HARRIS, N.B.W \& HAWKESWORTH, C. 1996. Geochemical constraints on crustal anatexis: a case study from the PanAfrican Damara granitoids of Namibia. Contributions to Mineralogy and Petrology, 123: 406-423.

MELHEM, M.M.1995. Geologia e petrologia das rochas granitoides do macico Atibaia e adjacências, SP. Master Thesis, Institute de Geociências, Universidade de São Paulo, 117 p. (unpublihed)

MONTEL, J.-M. 1993. A model for monazite/melt equilibrium and application to the generation of granitic magmas. Chemical Geology, 110(1/3): $127-1467$

OLFVEIRA, M.A.F. \& RUBERTI, E. 1979. Granada-cordierita gnaisses do complexo granulítico-migmatítico de São José do Rio Pardo-Caconde, SP: indicações sobre pressão e temperatura de formação. Boletim Mineralógico, Recife, 6: 15-29.

OLIVEIRA, MA.F; KAWASHITA, K· KIHARA, Y \& DELHAL, J. 1986. Novos dados geocronológicos para rochas charnoquíticas da Associação Guaxupe, Complexo Varginha. Rev. Brasili. Geoc., 16: 301-305.

PATINO DOUCE, A.E. \& JOHNSTON, A.D. 1991. Phase equilibria and melt productivity in the pelitic system: implications for the origin of peraluminous granitoids and aluminous granulites. Contributions to Mineralogy and Petrology, 107: 202-218.

PICHAVANT, M. \& MANNING, D. 1984. Petrogenesis of tourmaline granites and topaz granites; the contribution of experimental data. Phvsics of the Earth and Planetary Interiors, 35: 31-50.

RUSHMER, T. 1991. Partial melting of two amphibolites: contrasting experimental results under fluid-absent conditions. Contributions to Mineralogy and Petrology, 107: 41-59.

SAWYER, E.W. 1991. Disequilibrium melting and the rate of melt-residuum separation during migmatization of mafic rocks from the Grenville Front, Quebec. Journal of Petrology, 32: 701-738.

TASSINARI, C.C.G. 1988. As idades das rochas e dos eventos metamorficos da porção sudeste do Estado de São Paulo e sua evolução crustal. Doctoral Thesis, Institute de Geociências, Universidade de São Paulo, 236 pp. (unpublished)

TÖPFNER, C. 1996. Brasiliano-granitoide in den Bundesstaaten São Paulo und Minas Gerais, Brasilien-eiene Vergleichende studie. Munchner Geol. Hefte, A17,258 pp.

THOMPSON, A.B. \& CONNOLLY, J.A.D. 1995. Melting of the continental crust: Some thermal and petrological constraints on anatexis in continental collision zones and other tectonic settings. Journal of Geophysical Research, 100(88): 15565-15579.

VffiLZEUF, D. \& MONTEL, J.M. 1994. Partial melting of metagreywackes. Part I. Fluid-absent experiments and phase relationships. Contributions to Mineralogy and Petrology, 117: 375-393.

VASCONCELLOS A.C.B.C. HARRIS, N.B.W \& TINDLE, A.G. 1991. The relationship between metamorphism and tectonics: evidence from the Socorro-Guaxupé thrust nappe, southeastern Brazil. Res Terrae, Sér. A, number 5 (P. Tuisku \& K. Laajoki (Eds.): Metamorphism, deformation and structure of the crust- Abstracts), Oulu, Finland, p. 86

VLACH, S.R.F.; JANASI, V.A. \& VASCONCELLOS, A.C.B.C. 1990. The Itu belt: associated calc-alkaline and aluminous A-type late Brasiliano granitoids in the States of São Paulo and Paraná, Southern Brazil. In: Congresso Brasileiro de Geologia, 36, Natal, Sociedade Brasileira de Geologia Anais 4: 1700-1711.

WATSON, E.B. \& HARRISON, T.M. 1984. Accessory minerals and the geochemical evolution of crustal magmatic systems: a summary and prospectus of experimental approaches. Physics of the Earth and Planetary Interiors, 35: 19-30.

WATT, G.R. \& HARLEY, S.L. 1993. Accessory phase controls on the geochemistry of crustal melts and restites produced during waterundersaturated partial melting. Contributions to Mineralogy and Petrology, 114: 550-566.

WERNICK, E \& PENALVA, F, 1980. Contribuicao a geologia do Grupo Pinhal (SP e MG). Revista Brasileira de Geociencias, 10: 43-62.

WERNICK, E. \& GALEMBECK, T.M.B. 1987. Evolução geotectônica durante o Proterozóico Superior no Estado de São Paulo: uma contribuição através da análise do magmatismo granitóide. In: Simpósio Regional de Geologia, 6, Rio Claro, SP. Atas, 1: 191-204.

WERNICK, E.; HORMANN, P.K. ARTUR, A.C. \& EULERT, H. 1984 Aspectos petrológicos do complexo granítico de Socorro (SP/MG): dados analíticos e discussão preliminar. Revista Brasileira de Geociências, 14: 23-29.

WERNICK, E- WEBER-DEFENBACH, K \& CORREIA, PR 1987. O granitóide Nazaré Paulista: dados petrográficos, químicos e de tipologia do zircão. In: Simpósio Regional de Geologia, 6, Rio Claro-SP. Atas, SBG-NSP, 1:123-134.

WINTERS, A.A.M. 1981. A geologia do macico sienítico Pedra Branca, Caldas-MG. Master Thesis, Instituto de Geociências, Universidade de São Paulo, 92 p. (unpublished)

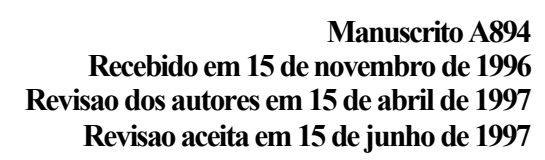

Manuscrito A894 Revisao aceita em 15 de junho de 1997 